\title{
INDDRAGELSE AF PERSONER MED DEMENS OG PÅRØRENDE I UDVIKLINGEN AF TRYGHEDS- SKABENDE DEMENSTEKNOLOGIER
}

\author{
DIANA SCHACK THOFT OG ANDERS KALSGAARD MØLLER
}

I de senere år er der kommet større fokus på velfærdsteknologier i demensomsorgen. Dette fokus retter sig dog primært mod sikkerhedsovervågning og sundhedsydelser snarere end forbedring af livskvaliteten for personer med demens (Evans et al. 2015). Velfærdsteknologier kan potentielt hjælpe med at fremme sikkerhed, fremme kommunikation, give multisensorisk stimulation og fungere som hukommelseshjælpemiddel. På trods af disse fordele er brugen af velfærdsteknologier i demensomsorgen begrænset (ibid.).

Personer med demens inddrages sædvanligvis ikke i forskningssamarbejder om udvikling af velfærdsteknologi, og der mangler derfor viden om, hvilke behov og ønsker personer med demens har. Det skyldes blandt andet, at demens historisk set har været associeret med stereotype forestillinger om ældre senile mennesker, som har mistet evnen til at ræsonnere (Wilkinson 2002). Der er imidlertid stor variation i gruppen af personer med demens og dermed også stor forskel i præferencer, accept af diagnose og niveau af selvhjulpenhed (Winblad et al. 2016; Yu 2009). Det er vigtigt at fă indsigt i de behov, ønsker og evner, som personer med demens har, for at undgå at designe uhensigtsmæssige eller uanvendelige teknologier.

Ved at ekskludere personer med demens risikerer man, at de teknologiske hjælpemidler ikke imødekommer de skiftende behov, der eksisterer ved en progressiv demenssygdom (Suijkerbuijk et al. 2019). Vigtigheden af at involvere personer med demens og deres pårørende i udviklingen af nye velfærdsteknologier er tidligere blevet fremhævet (Span et al. 2013; Meiland 2017; Holthe et al. 2019). Disse undersøgelser peger på, at personer med demens ofte indtager en passiv rolle i udviklingen af velfærdsteknologier, hvor de typisk bliver genstand for observationer eller først inddrages som informanter i evalueringsfasen. Der findes få undersøgelser, hvor personer med demens inddrages i idégenereringsfasen. Viden og metoder til at involvere personer med demens i disse udviklings- 
trin af velfærdsteknologi er derfor meget begrænset (Suijkerbuijk et al. 2019). Dog ved man, at inddragelse af personer med demens kan styrke deres følelse af kontrol (Hanson et al. 2007) og skabe en mere empatisk forståelse for brugergruppen (Lindsay et al. 2012). Samtidig kan det være udfordrende at inddrage personer med demens som meddesignere i udviklingen, da sygdommen påvirker kognition, herunder sprog og evnen til at tænke abstrakt (Suijkerbuijk et al. 2019).

I denne artikel tages der udgangspunkt i et offentlig-privat innovationsprojekt (OPI-samarbejde), hvor teknologiudvikler (OTIOM A/S) samarbejdede med en række kommuner, forskningsinstitutioner med flere om at udvikle et nyt alarmog pejlesystem (OTIOM) inden for demensområdet (OTIOM 2019). Som led i dette samarbejde er der blevet afholdt en række workshops, hvor personer med demens og deres pårørende er forsøgt inddraget som aktive meddesignere i idégenereringsfasen. Formålet med artiklen er at undersøge, hvordan og i hvor høj grad personer med demens og deres pårørende kan bidrage og tænkes ind i udviklingen af nye velfærdsteknologier med fokus på den idégenererende fase. Samtidig undersøges begge parters krav og forbehold i forhold til GPS-løsninger, herunder aspekter som overvågning, selvstændighed og sikkerhed.

\section{Baggrund}

Demens er en frygtet sygdom i vores samfund, da der fortsat ikke findes nogen forbyggende eller helbredende behandling (Rafii \& Aisen 2009). I dag beskrives demens som en paraplydefinition på over 200 forskellige demenssygdomme, som er karakteriseret ved kognitive og adfærdsmæssige symptomer forårsaget af degenerative forandringer i det centrale nervesystem (Tanner 2012). Forskningen på demensområdet har indtil nu hovedsageligt taget udgangspunkt i et biomedicinsk paradigme med fokus på at identificere sygdomsårsager og behandlingsmuligheder (Dougall et al. 2004). Det betyder, at der mangler forskningsviden inden for såvel det psykosociale som det velfærdsteknologiske område samt forskning, som involverer personer med demens (Sundhedsstyrelsen 2019; Thoft 2017; Thoft, Pyer, Horsbøl \& Parkes 2018). Et systematisk review af psykosociale interventioner for personer med demens konkluderer, at der fortsat er behov for længerevarende og metodologisk stærke undersøgelser med et større sample (McDermott et al. 2019).

Demens beskrives som et nationalt og globalt problem, da sygdomsincidensen og -prævalensen er stigende på grund af demografiske faktorer som stigende alder og flere ældre (Winblad et al. 2016). Ifølge Nationalt Videnscenter for Demens (2014) lever cirka 90.000 danskere med en demenssygdom, og ifølge nyeste fremskrivning forventes det, at antallet i 2040 vil være 164.000. På nuværende 
tidspunkt anslås de direkte omkostninger ved demens til cirka 24 milliarder kroner (Nationalt Videncenter for Demens 2014). Prognoser som denne fik i 2017 regeringen til at udarbejde en ny national demenshandlingsplan (Sundheds- og Ældreministeriet 2017). Et af initiativerne i handlingsplanen drejer sig om at skabe tryghed for personer med demens, som kan have vanskeligt ved tage vare på sig selv, når de bevæger sig uden for hjemmet. Det skaber ofte bekymring blandt pårørende og plejepersonale, som frygter, at personer med demens farer vild eller kommer til skade (Miyamoto et al. 2002).

En af løsningerne på denne udfordring er såkaldte mobile tryghedsalarmer med positionsbestemmelse (GPS) og tryghedsalarmer med automatisk aktivering ved udgang fra afgrænset område. I juli 2010 blev lovgivningen på området lempet, så det er muligt, at personer med demens, der ikke modsætter sig brugen af GPS, kan tildeles en sådan uden afgørelse herom på myndighedsniveau (Sundheds- og Ældreministeriet 2016).

I litteraturen findes undersøgelser, hvor fagprofessionelle og pårørende forholder sig til eksisterende elektroniske pejlesystemer (Landau et al. 2009; White \& Montgomery 2014), mens der er mindre fokus på, hvordan personer med demens forholder sig til disse systemer, selv om der er positive erfaringer med at inddrage personer med demens i processen og herigennem opnå indsigt $\mathrm{i}$ deres behov og ønsker til GPS-løsninger (Robinson et al. 2009). Konsekvensen af en manglende inddragelse kan være, at GPS-løsningerne bliver mindre brugervenlige og ikke accepteres, fordi de ikke matcher brugernes livssituation.

I en undersøgelse foretaget af Robinson et al. (2009) understreges vigtigheden af, at personer med demens kan bibeholde deres nuværende aktiviteter som for eksempel at cykle, gå ture og motionere. Deltagerne i undersøgelsen, som er personer med mild eller moderat grad af demens, oplever en høj grad af frihed og uafhængighed ved forsat at kunne være aktive. Dog kan de opleve en vis bekymring for at blive væk samt mangle tillid til egne evner. Deres forslag til mulige løsninger er for eksempel noget, der kan guide dem, hvis de bliver væk, eller et identitetskort, hvis de skal spørge om hjælp. I forhold til GPS og andre demenssikringsteknologier er de bekymrede for overvågningen, og om løsningerne begrænser dem i deres hverdag. Desuden er de bekymrede for, om de vil huske at få GPS'en med (ibid.).

Hos fagprofessionelle og pårørende findes forskellige holdninger til GPS-løsninger (Landau et al. 2009). Nogle føler sig forpligtet til at bruge løsningerne på grund af sikkerhed for personer med demens, mens andre er modstandere af systemerne, da de mener, at det går ud over personernes selvstændighed. Generelt peger flere undersøgelser på, at pårørende i højere grad er fortalere for brugen af GPS-systemer end de fagprofessionelle, da de vægter deres pårørendes sikker- 
hed og egen sindsro højest (Landau et al. 2009; Wan et al. 2014). Denne tendens bekræftes i en undersøgelse af White og Montgomery (2014), hvor ni ud af 10 pårørende giver udtryk for, at de vægter personens sikkerhed over hans/hendes privatliv og selvstændighed. Privatlivet vægtes, men hensynet til sikkerheden prioriteres højere (Wan et al. 2014; White \& Montgomery 2014). Ligeledes er der ikke tale om overvågning for overvågningens skyld, men som en ønskværdig mulighed, når det skønnes nødvendigt (Landau et al. 2009; Wan et al. 2014; White \& Montgomery 2014).

Overordnet set synes der at være en række udfordringer med GPS-systemerne. Det gælder også i forhold til systemernes udseende, form og design med mere (Mahoney \& Mahoney 2010; Robinson et al. 2009), hvilket kan medføre, at personer med demens ikke er interesseret $\mathrm{i}$ at anvende og bære løsningerne (Mahoney \& Mahoney 2010). Yderligere finder mange pårørende og fagprofessionelle GPS-systemerne vanskelige at betjene (Wan et al. 2014) og ønsker mere fleksible løsninger, så de i højere grad kan tilpasses den enkeltes behov. Samtidig kan et GPS-system løbe tør for strøm og herved skabe mistro til systemet grundet svigtende pålidelighed (Wan et al. 2014). I udviklingen af nye alarm- og pejlesystemer er det derfor vigtigt at inddrage såvel personer med demens som deres pårørende for at adressere deres behov og ønsker. Hvis ikke risikerer man, at systemerne ikke anvendes.

\section{Tilgangen}

I samarbejdet med personerne med demens og deres pårørende anvendtes en participatorisk designtilgang. Inden for sundhedsområdet er den participatoriske tilgang blandt andet inspireret af aktionsforskningen, voksenuddannelse og medicinsk antropologi (Cornwall \& Jewkes 1995). I participatorisk forskning anvendes såvel klassiske kvalitative som kvantitative metoder samt mere kreative brugerinvolverende metoder som collagearbejde, interaktivt teater og samfundsmøder (Stacciarini et al. 2011; Dewar 2005). I forhold til participatorisk design beskriver Sanders (2002), hvordan man i stedet for at designe for brugeren designer med brugeren, hvilket betyder, at brugeren bliver en aktiv del af designog udviklingsforløbet. Til at understøtte denne proces foreslår Sanders en række værktøjer, som opfordrer brugerne til at designe og samskabe som en hjælp til at udtrykke deres tanker, følelser og drømme. Hun argumenterer for, at man ved både at udforske, hvad folk gør, siger og skaber, kan opnå en større indsigt og en empatisk forståelse af folks holdninger (Sanders 2002).

I vores undersøgelse blev deltagerne aktivt involveret i design- og udviklingsfasen, da vi anvendte brugerinvolverende workshops, hvor fokus var på samska- 
belse via brug af kreative generative værktøjer. Eksempelvis blev input fra hver workshop opsamlet og formidlet som poster til næste workshop for at understøtte deltagernes hukommelse samt afklare, hvorvidt vi havde forstået deres input korrekt. Derudover benyttede vi for eksempel billeder, tegninger og 3D-printede prototyper til at støtte deltagerne $\mathrm{i}$ at sætte ord på deres behov og udfordringer samt lave illustrationer og skabe forskellige løsninger. I workshopperne fungerede vi som ordstyrere, men samtaleemnerne var i høj grad deltagerstyrede.

Rekrutteringen af personer med demens og deres pårørende foregik i Aalborg Kommune via Videnscenter for Demens. Efter aftale deltog vi i nogle af kommunens tilbud, hvor vi præsenterede os selv og vores forskningsfokus for efterfølgende at afholde workshops med deltagerne. Dette første møde var med til at skabe en relation til deltagerne. Inklusionskriterierne var en kendt demensdiagnose, interesse $i$ at indgå $i$ et GPS-teknologiudviklingsprojekt samt at være $i$ stand til at kommunikere sine budskaber til andre. Ligeledes skulle deltagerne kunne forstå og underskrive en samtykkeerklæring. I projektet deltog ni personer (fire kvinder og fem mænd) fra Aalborg Demens Skole (ADS), som er et ugentligt skoletilbud med kognitiv stimulation for personer med en mild demens (Videncenter for Demens, Aalborg Kommune 2019). Ligeledes deltog 11 personer (fire kvinder og syv mænd) fra Aktiv med Demens (AmD), som er et ugentligt aktivitetstilbud, som indbefatter forskellige tilbud såsom fysisk træning, musik og demenscafé (Aktiv med demens 2019). Deltagerne var yngre med mild til moderat demens. Deltagerne med demens boede stadig i eget hjem og var forholdsvis selvhjulpne, hvilket vil sige, at de med støtte kunne klare de fleste hverdagsaktiviteter. Der deltog syv pårørende (syv kvinder, hvoraf fem var ægtefæller, og to var døtre) fra en pårørendegruppe forankret ved AmD, hvor nogle af personerne med demens boede $\mathrm{i}$ eget hjem, mens andre var flyttet på plejehjem. I hver workshop deltog fagprofessionelle, som normalt varetog de aktiviteter, som deltagerne gik til. De bidrog med støtte og vejledning i workshopperne, men ikke til idéudviklingen af GPS-løsningen.

De rekrutterede deltagere deltog i tre workshops af en-to timers varighed: én for hver gruppe af personer med demens (ADS og AmD) og én for pårørende (AmD). I workshopperne for personerne med demens tog vi udgangspunkt $\mathrm{i}$ deres observerede kompetencer og udfordringer fra det indledende møde. Det var væsentligt at reducere og simplificere de brugerinvolverende processer til det mest essentielle samt at nedbryde processerne til håndterbare opgaver. I workshopperne forsøgte vi at være fleksible og omstillingsparate. Det betød, at vi støttede deltagerne i udførelsen af opgaverne og/eller ændrede opgaverne, så det var muligt for alle at give deres mening til kende. Dette var udfordrende på grund af gruppernes størrelse og tilbageholdenhed hos enkelte af deltagerne. I forhold til 
de pårørende måtte vi afkorte workshopperne til cirka en times varighed, da de havde vanskeligt ved at afse mere tid pr. gang på grund af en belastet hverdag.

I hver workshop anvendte vi deltagende observation (Bjørner 2015; Hammersley \& Atkinson 2007) med lydoptagelse og nedskrivning af feltnoter for at fastholde de behov og ønsker, som deltagerne formulerede (Groes 2015). Lydoptagelserne og feltnoterne bidrog til, at vi fik overblik over processen, da det var vanskeligt både at have fokus på deltagelse i workshopperne og observere, hvad der foregik i gruppen. Det var en fordel at sidde sammen og drøfte feltnoterne efter hver workshop. Samtidig bidrog det til at lægge planer for næste workshop baseret på indhentet viden (Hubbard 2003).

\section{Etiske overvejelser}

Alle deltagere modtog mundtlig og skriftlig information om projektet og skulle udfylde et skriftligt informeret samtykke. For personerne med demens blev der udarbejdet et særligt informationsmateriale og samtykke med udgangspunkt i Alzheimer Europes anbefalinger (Alzheimer Europe 2012) og erfaringer med involvering af personer med demens i forskningsprojekter (Thoft 2017; Thoft et al. 2018). ${ }^{1}$

Ud over formelle etiske forholdsregler eksisterer der også en række praktiske etiske forhold, som bør adresseres, når man arbejder participatorisk. Det gælder især, når man samarbejder med sårbare brugere som personer med demens, da de kan have vanskeligt ved at indgå i vanlige forskningssamarbejder (Hellström, Nolan \& Lundh 2007). Vi måtte tage hensyn til deres kognitive udfordringer, som ud over hukommelsesproblemer indbefattede koncentrationsbesvær, sprog- samt læse- og skriveproblemer (Alz.org. 2015). Det var derfor nødvendigt at planlægge detaljeret, hvordan vi skulle afholde de enkelte workshops, og arbejde med flere tilgange, hvis det viste sig, at vores oprindelige planer ikke var realiserbare. Det var hele tiden nødvendigt at medtænke vores viden om demens og vores kendskab til den enkelte deltager for at sikre en etisk sensitiv tilgang (Heggestad et al. 2012). I en sådan tilgang lægges vægt på transparens, ærlighed og åbenhed, hvor der lyttes til deltagernes meninger og forståelse igennem forskningsprocessen (ibid.; McKeown 2010). Dette var udfordrende på grund af deltagernes koncentrations- og sprogproblemer. Koncentrationsproblemerne udfordrede blandt andet deltagernes forståelse af, hvad det var, vi gerne ville have dem til. Det krævede meget instruktion og guidning, hvilket ikke altid var muligt at tilbyde alle i gruppen. Samtidig kunne det være vanskeligt for os at kommunikere med nogle af personerne med demens på grund af sprogproblemer. Her fik vi støtte fra fagprofessionelle, som allerede kendte deltagerne. Samtidig 
var vi opmærksomme på at bruge et konkret og enkelt sprog. Det var ligeledes udfordrende at sikre en personcentreret tilgang (Kitwood 1997). Det skyldtes, at flere af deltagerne var forbeholdne i starten af projektet, hvilket gjorde det vanskeligt at forstå deltagernes perspektiv samt opbygge et støttende miljø omkring alle deltagerne (Kitwood 1997). Yderligere oplevede vi, at enkelte deltagere var frembrusende, mens andre var tilbageholdne og apatiske. For at inkludere og give stemme til alle vekslede vi derfor mellem plenum og en-til-en-kontakt. Både i forhold til den personcentrerede tilgang og muligheden for at aktivere alle var de fagprofessionelles støtte vigtig. I visse tilfælde oplevede vi, at der var forskellige virkelighedsopfattelser blandt personerne med demens og deres pårørende. Vi understøttede, at alle perspektiver blev inkluderet, og konstaterede, at de forskellige opfattelser både kunne skyldes manglende selvindsigt, og at man ikke ønskede at dele sine udfordringer med andre. Disse forskellige opfattelser uddybes i afsnittene „Resultater“ og „Diskussion“.

Yderligere er det relevant at adressere de etiske udfordringer, der kan opstå $\mathrm{i}$ et OPI-samarbejde, hvor der kan være forskellige interesser. Virksomheder er generelt optaget af at produktudvikle med henblik på salg, mens øvrige deltagere kan være optaget af såvel processen som det færdigudviklede produkt. I samarbejdet med OTIOM A/S blev der indgået aftale om ansvars- og rollefordelingen ved involveringen af brugerne. Det var os, der havde det overordnede ansvar, mens firmaet forbeholdt sig retten til ikke at inkludere alle inputs. Dette rejste et etisk dilemma, som blev forsøgt håndteret ved at forklare deltagerne, at det måske ikke var muligt for firmaet at imødekomme alle ønsker og behov til deres førstegenerationsløsning. I praksis betød det, at flere ønsker blev fravalgt af virksomheden, da det ikke passede ind i deres vision, forretningsplan og planlagte udviklingstid, mens andre idéer blev gemt til udviklingen af anden generation og som viden til udarbejdelse af nye fremtidige produkter.

\section{Analysetilgang}

De indsamlede data i form af lydoptagelser fra workshopperne blev transskriberet og anonymiseret (i forhold til GDPR) med identifikation af deltager/facilitator. Disse blev suppleret med feltnoterne. Dataanalysen var inspireret af den tematiske analyse (Braun \& Clarke 2006; Clarke \& Braun 2013), som er en grundlæggende kvalitativ analytisk tilgang. Analysen var karakteriseret ved en induktiv datastyret tilgang, hvilket resulterede i temaer, som er tæt knyttet til data. Kodningen af data skete uden relation til et bestemt rammeværk eller en bestemt analytisk (for)forståelse (Braun \& Clarke 2006). Se illustration af de seks analysefaser i figur 1. 


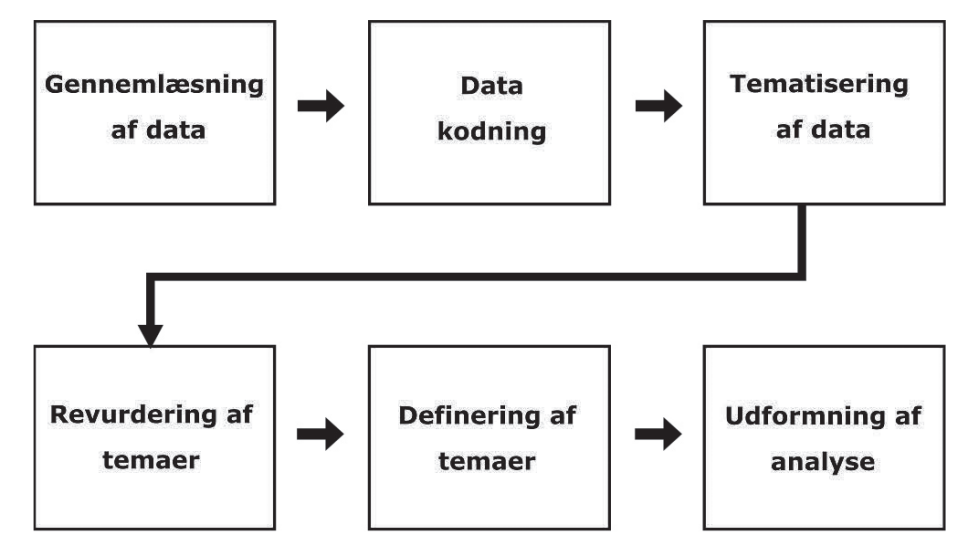

Figur 1: Oversigt over analysefaser.

I fase 1 læste vi og en forskningsassistent transskriptionerne igennem hver for sig for at danne os en indgående forståelse af data. I fase 2 mødtes vi og forskningsassistenten og kodede data. Forskningsassistenten blev inddraget $\mathrm{i}$ analysearbejdet for at sikre, at vi ikke kodede ud fra en bestemt forforståelse, som indskrænkede en induktiv tilgang. Fase 3 blev også udarbejdet i et samarbejde, ved at alle koder blev grupperet med en mulig overskrift, som kunne samle grupper af data på tværs af transskriptionerne. Analysen fra fase 4-6 blev udarbejdet og rundsendt mellem os, til vi var blevet enige.

\section{Resultater}

I dette afsnit præsenteres resultaterne af analysen. Vi indleder med temaet Udfordringer med at finde vej, som beskriver de udfordringer og bekymringer, som personerne med demens og deres pårørende oplever ved at finde vej. Derefter følger temaet Bekymringer og udvikling af strategier, der berører de bekymringer og strategier, der er en del af livet med demens. Temaet Nuvcerende løsninger omhandler de teknologiske løsninger, som personer med demens og deres pårørende anvender eller har anvendt. Temaet Fremtidig løsning til at finde vej beskriver de ønsker til og behov for en GPS-løsning, som personerne med demens og deres pårørende har. Endelig præsenteres temaet Behov for autonomi og tryghed, som illustrerer, hvordan pårørende og personerne med demens forholder sig til dilemmaet mellem bevægelsesfrihed kontra sikkerhed og tryghed.

Temaet Udfordringer med at finde vej omhandler de situationer, hvor såvel personerne med demens som deres pårørende oplevede, at demenssygdommen påvirkede evnen til at finde vej. Personerne med demens var bevidste om, at de havde problemer med at huske, og at det især var korttidshukommelsen, der 
var påvirket. Der var dog flere, som påpegede, at de stadig var i stand til at gøre mange ting som for eksempel at gå ture, cykle, køre bil, bruge mobiltelefon og GPS. De kunne finde rundt på velkendte steder, hvor de anvendte forskellige strategier til at orientere sig. Dog kunne forandringer i bybilledet eller meget ensartethed skabe forvirring. Flere nævnte også, at det var vanskeligt at finde rundt efter anvisninger, idet korttidshukommelsen gjorde, at man ikke kunne huske hele anvisningen. Deltagerne var altså i høj grad klar over deres begrænsninger og udviklede forskellige strategier til at kompensere for disse. En strategi kunne være at bevæge sig rundt i kendte omgivelser, hvor man opbyggede rutiner og landkendinger og havde faste ruter. Nogle fortalte, hvordan de var flere, som gik sammen i det område, hvor de boede. Andre ønskede stadig at gå ture alene. En mandlig deltager med demens fortalte, at hans strategi indbefattede at skabe sig landkending:

Man kan ikke få noget sådan: Okay, det var der, der var den bygning, eller der var den bygning, der var den statue eller et eller andet, du kan genkende, sådan at du kan få noget retning på. Det er sådan set mit største problem. For ellers så er jeg sådan rimelig god til at finde rundt, hvis bare jeg er et sted, hvor jeg kan finde noget landkending.

Det viser, at flere på trods af problemer med at finde rundt forsøgte at finde strategier til fortsat at bevæge sig rundt i lokalsamfundet. Dog blev de ofte udfordret, hvis de bevægede sig uden for kendte omgivelser.

Konkrete historier i nyhederne om personer med demens, der var faret vild og senere omkommet, skabte også nervøsitet. Det var for enkelte forbundet med utryghed at bevæge sig rundt på egen hånd. For nogle betød det, at de ikke længere gik ud, når det blev mørkt. En kvindelig deltager med demens fortalte, at det både var mørket og usikkerheden generelt, som gjorde, at hun ikke længere bevægede sig rundt på egen hånd: ,Jeg kan heller ikke lide at gå i mørke alene, men det er ikke bare derfor, det er utrygt. "Nogle personer med demens opholdt sig således meget hjemme og kom ikke ud så ofte, som de ellers gerne ville. I workshopperne for pårørende beskrev de også, at de var utrygge ved, at deres pårørende med demens bevægede sig rundt på egen hånd, især når det var mørkt. En pårørende fortalte, hvordan hun havde aftalt med ægtefællen, at han ikke længere gik ud om aftenen. Begrænsninger i bevægelsesfriheden skyldes altså også pårørendes bekymring for, at personer med demens ikke kan orientere sig.

Næste tema Bekymringer og udvikling af strategier viste, hvordan de pårørende oplevede at leve $\mathrm{i}$ en presset hverdag med et kæmpe ansvar i forhold til deres pårørende med demens, som kunne være en ægtefælle, en forælder eller en søskende. Pårørende levede med daglige bekymringer, følte sig belastet og var usikre på, hvad fremtiden ville bringe. De forklarede, hvordan det var 
hårdt at skulle tage mere over i hjemmet, og hvordan forholdet blev udfordret af demensen. Deres bekymringer udsprang ofte af konkrete episoder, hvor for eksempel en pårørende fortalte, at hendes mor var blevet kørt hjem af politiet, da hun ikke selv kunne finde vej:

Ja, det gjorde vi med min mor også, der hvor hun kom hjem med politiet. Hun var sådan lidt, hun prøvede at berolige os ... hun kunne godt forstå bekymringen og kunne godt forstå ... Min far talte jo også med hende, man når jo også at blive bange nogle gange. Det var vigtigt, at hun blev hjemme.

Familien var ofte bekymret for, at deres pårørende med demens gik hjemmefra. Denne bekymring blev bekræftet af personerne med demens, som fortalte, at de var opmærksomme på, at deres pårørende var bekymrede på deres vegne, og forsøgte at beskytte dem. De oplevede på den måde, at demenssygdommen også havde en negativ betydning for deres forhold. De forandringer, demensen medførte, var vanskelige at håndtere for såvel dem selv som for de pårørende. På workshopperne talte personerne med demens om, hvordan de oplevede, at pårørende var bekymrede for, om de kunne finde rundt på egen hånd. Det kunne betyde, at pårørende ikke altid ønskede eller ville lade dem gå alene. En kvindelig deltager med demens fortalte, at hun ikke fik lov til at gå eller rejse alene, fordi hendes ægtefælle var bekymret for hende:

Ja, det får jeg ikke lov til. Selv om jeg siger en gang imellem, at det skal han ikke blande sig i [griner]. Når jeg rejser over til min søster i København, hvad enten det er med bus eller tog, det øh, det tør han ikke lade mig gøre.

Pårørende udviklede derfor forskellige løsninger for at skabe mere tryghed $\mathrm{i}$ hverdagen som for eksempel at køre og hente deres pårørende med demens eller lave aftaler i forhold til at bevæge sig uden for hjemmet. Det var dog ikke altid, at de aftaler blev opfattet positivt af personerne med demens, og der kunne opstå diskussioner om, hvorvidt personen med demens selv kunne gå og rejse alene. Personerne med demens fortalte, at det var vanskeligt at lave disse aftaler og overholde dem, da man let kunne miste tidsfornemmelsen, når man var ude at gå. Det betød, at aftaler kunne give anledning til bekymring hos pårørende.

Flere af deltagerne med demens forholdt sig ligeledes kritisk til, om deres pårørende altid skulle vide, hvor de var. Det skyldtes, at de oplevede, at deres pårørende blev overbeskyttende og havde mere fokus på sygdommen, end de selv havde, og de var derfor ikke altid enige med deres pårørende. Omvendt nævnte de pårørende, at personerne med demens ikke altid havde indsigt i egen formåen og kompetencer. Generelt ønskede personerne med demens ikke at belaste deres pårørende og blev kede af det, hvis det skete. Det kunne være en øjenåbner for 
dem, hvis de var blevet kørt hjem af politiet, fordi de ikke selv kunne finde vej. Under temaet Nuvcerende løsninger fortalte de pårørende, at de brugte mobiltelefoner til at komme i kontakt med deres pårørende med demens, og enkelte fandt en tryghed $i$ at vide, at de kunne bruge iPhones indbyggede sporing ,Find-MyiPhone" til at lokalisere deres pårørende, hvis det blev nødvendigt. Der var dog et problem med strøm, da flere ikke huskede at få telefonen opladet. En person med demens fortalte ligeledes, at hun ikke altid svarede på sin mobiltelefon, når hun var ude at gå, og at det skabte bekymring hos hendes døtre, hvis hun var væk i længere tid:

Ja, men også det der, hvis man er et sted, og man står og snakker med nogen, så begynder den der rent ud sagt forbandede telefon at klirre nede i tasken, og jeg smider ikke, hvad jeg har, for så at se, hvad det er, og så er der så en af mine døtre, der siger: 'Jamen, nu har vi lige været så bekymrede', og så sagde jeg, 'Jamen, hvis I skulle være bekymrede, så havde jeg nok ringet og sagt, at jeg var ved at dø’ [griner].

Det kunne også være, at personen med demens ikke hørte sin mobiltelefon, hvilket betød, at de pårørende ikke altid oplevede mobiltelefonen som en optimal løsning - især ikke efterhånden som demensen progredierede, og personen måske ikke længere kunne finde ud af at bruge sin mobiltelefon. Personerne med demens anvendte deres mobiltelefon i forskelligt omfang. Nogle brugte den slet ikke, mens andre overvejende brugte den til at modtage opkald.

Flere havde erfaring med brug af eksisterende GPS-løsninger i for eksempel skosåler, Doro-telefon med mere. De havde varierende oplevelser med de eksisterende løsninger. De pårørende troede, at de fremtidige løsninger kun kunne blive bedre, idet de havde oplevet minusser ved alle eksisterende løsninger, de havde afprøvet. Mange af løsningerne holdt ikke strøm, så der var et ønske om bedre batterilevetid. Derudover var løsningerne store, og designet var ikke noget, som personerne med demens eller pårørende kunne relatere sig til. Flere oplevede også, at de nuværende løsninger var vanskelige at betjene, og de ønskede derfor enkle løsninger.

I forbindelse med temaet Fremtidig løsning til at finde vej viste det sig at være vigtigt for de pårørende, at den udviklede løsning blev introduceret tidligt, så der kunne opøves en vane/rutine, hvor personen med demens tog løsningen med sig. De fremhævede desuden, at det var godt, hvis løsningen motiverede personerne til at gå mere, hvorved de ville opleve større frihed. For pårørende var det ligeledes vigtigt, at en fremtidig løsning kunne følge personen med demens gennem hele sygdomsforløbet. De pointer blev også delt af personerne med demens, hvor man var positiv over for at anvende GPS-løsningen som et eget hjælpemiddel, hvor man selv i starten af forløbet kunne bruge løsningen aktivt til at finde rundt. Løsningen kunne herved hjælpe mod nervøsitet i forhold til at finde vej: 
Den der dims skulle jo netop gerne gøre sådan, at det geografiske område, vi kunne færdes på, det blev lidt større. At man egentlig turde.

Flere af personerne med demens fortalte, at de endnu ikke selv havde brug for en GPS-løsning, men at den kunne være relevant for personer med demens, som havde vanskeligt ved at finde rundt. Der var dog enkelte, som allerede var brugere. Det illustrerer, hvordan deltagerne i varierende grad havde lyst til at fortælle om deres vanskeligheder med at finde vej.

De fleste deltagere med demens anså mobiltelefonen som deres førstevalg til at finde vej. De foreslog, at der blev installeret en hjælp-mig-knap, som kunne guide én hjem. Det blev ligeledes drøftet blandt såvel pårørende som personerne med demens, om det var muligt med flere udgaver af GPS-løsningen, som kunne udvikle sig i takt med sygdomsprogressionen. En mandlig deltager med demens forklarede:

Når vi begynder at få brug for jeres [løsning], så er vi faldet i niveau, og som I også siger, der ikke er teknisk - det skal virkelig næsten være sådan, at der bare er én knap, der siger 'hjælp mig'. Altså, der må ikke være ret meget, for så vil de fleste ikke kunne bruge den selv. Så er det selvfølgelig o.k., at der er nogle plejehjem og andre, der så kan finde én, det er jo en rigtig god ting.

Løsningen skulle kunne installeres til et niveau, som var passende. I starten kunne løsningen være en attrap, så man blev vant til at tage den med sig, selv om man ikke havde behov for den. Senere kunne den integrere en faldalarm, hvor pårørende og personale fik ansvaret for at sikre, at personen med demens havde GPS-løsningen med sig og kunne blive lokaliseret ved behov. Det var dog vigtigt, at disse funktioner kunne integreres i samme løsning, eller at udseendet på dem var forholdsvis ens. Hvis der ikke var en høj grad af genkendelighed, ville løsningen ikke blive brugt. Ydermere blev det gentagne gange nævnt fra alle deltagerne, at der var et behov for enkle løsninger, der kunne tilpasses individuelt, både når det gjaldt funktioner og design. Pårørende foreslog desuden, at man designede en løsning, som passede til personens vaner, eller noget, som personen i forvejen gik med som for eksempel et ur, for: „Hvis det er noget, man ikke forstår, man skal tage på, så gør man det nok ikke." Det var derfor vigtigt, at løsningen blev tilpasset personens vaner, forklarede en kvindelig pårørende.

For de pårørende gav det mening, at løsningen havde zoner, som var knyttet til alarmer, når disse blev overskredet. Det var vigtigt, at disse alarmer kunne indstilles individuelt. De ønskede at understøtte deres pårørendes frihed til at bevæge sig rundt, såfremt det kunne ske nogenlunde sikkert. Pårørende kunne se det nyttige $i$ en dobbelt konstruktion med både en „hjælp-mig“-funktion og en alarm, hvor personen med demens selv kunne aktivere løsningen. Personerne 
med demens talte ligeledes om muligheden for, at „hjælp-mig“-funktionen blev stemmestyret med mulighed for at give dem instruktioner til at finde hjem. Dog var de bange for, at en pludselig stemme kunne forvirre dem, hvilket pårørende også var bekymrede for. Personerne var desuden bange for, at de kunne komme til aktivere en alarmknap ved et uheld, og generelt at anvende den, da de ikke ønskede at skabe bekymring hos deres pårørende. Efter flere drøftelser ønskede de begrænsede funktioner for ikke at komme til at gøre noget forkert. Det betød, at såvel personerne med demens og deres pårørende endte med at ønske en enkel GPS-løsning, hvor risikoen for forkert brug var minimeret.

Temaet Behov for autonomi og tryghed viste, hvordan personerne med demens følte et stort behov for at leve så selvstændigt som muligt og ønskede deres autonomi og bevægelsesfrihed respekteret. Det var vigtigt for dem at være så selvhjulpne som muligt, hvilket betød, at den udviklede GPS-løsning skulle sikre dem en frihed og en tryghed til at bevæge sig rundt i lokalsamfundet. De ønskede at være i stand til at kunne finde vej så længe som muligt og uden at gøre andre urolige. Flere fortalte dog, at deres pårørende var begyndt at tage over for dem og sætte grænser for dem. De havde forståelse for de pårørendes bekymring, selv om de ikke syntes, de behøvede at være så bekymrede. De kunne derfor føle sig begrænset af deres pårørende og satte spørgsmålstegn ved nødvendigheden af, at de tjekkede op på dem, hvilket skabte konflikter.

De pårørende var meget interesserede $\mathrm{i}$ at høre, hvilke muligheder en GPSløsning kunne tilbyde dem i hverdagen, idet de håbede, at teknologien kunne give mere frihed for såvel personerne med demens som for dem selv. De anerkendte, at personerne med demens havde behov for selvstændighed og autonomi på den ene side, men påpegede på den anden side, at de også havde behov for omsorg og tryghed. De nævnte, at de tryghedsforanstaltninger, man iværksatte, kunne medvirke til, at personen med demens kunne blive længere tid i eget hjem.

Der var delte meninger blandt personerne med demens om det at introducere GPS-løsninger, som kunne overvåge deres færden for at imødekomme de pårørendes bekymring. Nogle forholdt sig kritisk til overvågningen, idet de beskrev det nærmest som fængselsagtigt og en pestilens, mens andre beskrev det som en tryghed og hjælp. Det var en drøftelse mellem behovet for autonomi og selvbestemmelsesret kontra behovet for tryghed og sikkerhed via overvågning. For at acceptere en overvågning var det vigtigt for personerne med demens, at det var nogle, de havde tillid til. Det kunne være en kontaktperson/livline, som kunne være ens nærmeste pårørende. En kvindelig deltager fortalte:

Jeg synes, det er godt, men det skal være nogle aftaler med nogle, der kender hinanden godt. Jeg vil ikke ret gerne have det sådan, at hvermand kan følge med $i$, hvor jeg er henne. 
Som citatet illustrerer, ville personerne med demens selv gerne være med til at træffe aftaler om, hvem der skulle have mulighed for at overvåge dem. Det skulle være dem, som var tættest på dem, det kunne være naboer og familie (børn og børnebørn). De nævnte, at naboer ofte var dem, som var tættest på én, da familien kunne bo langt væk, og det derfor ikke altid gav mening, at det var familien, som overvågede dem.

\section{Diskussion}

I vores undersøgelse fik personerne med demens og pårørende mulighed for at udtrykke deres ønsker til og behov for en fremtidig GPS-løsning. Undersøgelsen involverede personer, som på trods af kognitive udfordringer grundet demensen stadig var forholdsvis selvhjulpne og med et ønske om forsat at være det. Dog eksisterede en vis usikkerhed $i$ gruppen om egne evner og en bekymring for at blive væk eller gå forkert, hvilket begrænsede nogle i deres hverdag. Samme overvejelser ses i en undersøgelse af Robinson et al. (2009), hvor personerne med demens var bekymrede for at blive væk. Pårørende delte i høj grad denne bekymring. Personerne med demens oplevede, at denne bekymring fik pårørende til at blive overbeskyttende, hvilket kunne skabe konflikter. Vores undersøgelse viste dog, at personerne med demens til en vis grad accepterede denne overbeskyttelse, fordi de ikke ønskede at bekymre deres pårørende. På samme måde var der fra de pårørendes side forståelse for, at personer med demens stadig havde brug for deres selvstændighed og bevarelse af deres hverdagsaktiviteter. Det stemmer overens med andre undersøgelser (White et al. 2014; Wan et al. 2014), hvor dilemmaet mellem bevægelsesfrihed og sikkerhed fremføres af de pårørende. Trods konflikter og diskussioner lykkedes det også almindeligvis de involverede parter at finde kompromiser, da de havde en vis forståelse for hinandens behov.

Begge grupper beskrev deres forventninger til, hvad en GPS-løsning skulle bidrage til for at gøre hverdagen lettere. For personerne med demens handlede det om, at løsningen skulle hjælpe dem til at klare sig selv og dermed mindske de pårørendes bekymring og ansvar. De erkendte dog, at der kom et tidspunkt i fremtiden, hvor pårørende måtte tage over. Dette viste, at personerne med demens til en vis grad havde indsigt $i$ egen situation. Pårørende derimod mente, at det var dem, der var den aktive part i at skabe tryghed og sikkerhed, da de var usikre på, hvor meget selvindsigt deres pårørende med demens havde i forhold til at vurdere egne evner til at finde rundt. De havde oplevet situationer, hvor personerne med demens ikke kunne finde hjem. Hermed understøtter denne undersøgelse, at pårørende på baggrund af allerede oplevede situationer kan vægte sikkerhed højere end selvstændighed. Generelt ser det ud til, at pårørende er gode 
til at lytte til de behov og ønsker, personer med demens har. Dog er det i sidste ende de pårørende, som dikterer behovet for sikkerhed og tryghed, hvilket kan skabe en negativ magtbalance i forholdet.

Begge grupper understregede vigtigheden af at få introduceret hjælpemidlet tidligt, mens personen med demens stadig var nogenlunde selvhjulpen og $\mathrm{i}$ stand til at forholde sig til GPS-løsningen. Herved var det muligt at blive fortrolig med og tryg ved løsningen, da der kunne opbygges en vane med at anvende den, inden det blev nødvendigt. Ligeledes var der stort fokus på, at GPS-løsningen skulle tilpasses den enkelte person med demens med udgangspunkt i dennes situation og behov. Det stemmer overens med Kitwoods (1999) tilgang til personcentreret omsorg, hvor man tager udgangspunkt i den enkelte person, og hvordan netop dennes demenssygdom kommer til udtryk. Overordnet tegnede der sig et billede af en løsning, som gradvist flytter kontrollen fra personen med demens til pårørende. I starten fungerer den som et hjælpemiddel, der hjælper personen med at orientere sig, for senere at overgå til et system, der alarmerer pårørende, når det er nødvendigt. Det betyder, at såvel personerne med demens som pårørende ser det som muligt at have tryghedsskabende GPS-løsninger, hvis blot de introduceres tidligt nok og tilgodeser begge parters behov. Ligeledes er det vigtigt, at løsningen er enkel, så både personen med demens og pårørende kan og ønsker at anvende den.

I forhold til overvågningsaspektet er der delte meninger. Der synes dog at være enighed om, at overvågning er okay, når der er et konkret behov, og så længe overvågningen bliver begrænset til nogle få mennesker som for eksempel nærmeste pårørende eller nabo. Det betyder, at overvågningsperspektivet måske er mindre problematisk, så længe overvågningen er begrænset til nogle få, man er tryg ved og har tillid til. Denne viden er vigtig at bidrage med til samfundsdebatten om autonomibegrebet og overvågningsaspektet inden for demensområdet.

Det kan så diskuteres, hvornår der opstår et konkret behov, og det var da også tydeligt, at der var forskellige opfattelser blandt personerne med demens og pårørende om, hvor stort behovet var. Det er derfor vigtigt at diskutere dette tidligt i forløbet, mens personerne med demens stadig kan forholde sig til det, for at sikre mest mulig medbestemmelse og dermed en højere grad af accept fra personen med demens. En vigtig pointe i denne debat er, at pårørende og personer med demens påpeger, at en GPS-løsning kan medvirke til at skabe frihed, da personerne med demens kan bevæge sig frit rundt og kan lokaliseres ved behov. Pårørende antager, at det kan betyde, at personer med demens kan blive længere tid i eget hjem.

Ved at inddrage personer med demens kan man opnå et nuanceret billede af teknologien og overvågningsaspektet. Det blev pointeret i en undersøgelse af 
Robinson et al. (2009), hvor det fremhæves, hvordan personerne med demens i starten så demenssikringen som deres hjælpemiddel, hvilket formodes at kunne øge accepten af overvågningen og dermed mindske de udfordringer, der nævnes $i$ andre undersøgelser (Mahoney et al. 2010; Wan et al. 2014), hvor personerne med demens tog GPS-løsningen af eller ikke ønskede at gå med den.

De personer med demens, som deltog i workshopperne, havde demens i mild til moderat grad, og flere syntes derfor ikke, det var aktuelt med en GPS-løsning. Dog mærkede de dagligt de udfordringer, som sygdommen medførte, og gav bud på, hvordan løsningen skulle se ud for at hjælpe dem i fremtiden. Omvendt var der enkelte, som brugte GPS, da sygdommen var mere fremskreden. De beskrev den aktuelle situation, hvor en GPS var ønskelig. Deltagerne med demens repræsenterede derfor både personer, som stod over for at overveje en løsning i nærmeste fremtid, og personer, som allerede var brugere. De var i stand til kritisk at forholde sig til design og funktion af eksisterende og fremtidige løsninger. Herved bidrager undersøgelsen til den begrænsede viden, der på nuværende tidspunkt eksisterer om inddragelse af personer med demens i idégenereringsfasen af produktudvikling (Suijkerbuijk et al. 2019). I forhold til kritik af de eksisterende GPSløsninger, der findes på markedet i dag, var det især de pårørende, som forholdt sig kritisk, da de blandt andet oplevede problemer med batterilevetid og manglende anvendelse af løsningerne blandt personerne med demens.

Afsluttende kan det bemærkes, at samarbejdet med personerne med demens bød på forskellige udfordringer. Generelt kan man tale om, at en participatorisk tilgang er tidskrævende, da man som forsker må investere tid i at identificere relevante gatekeepers i forhold til en sårbar gruppe som personer med demens. Det tager tid at træffe aftaler og planlægge workshops i forhold til de kompetencer og overskud, deltagerne har. I vores undersøgelse oplevede vi samme kognitive udfordringer såsom sprog og evne til at tænke abstrakt, som Suijkerbuijk et al. (2019) fremhæver. Det betød, at det var vigtigt at tilrettelægge processen ud fra en relevant struktur med repetition, hvor enkelhed, tydelighed og afgrænsning af workshopperne var altafgørende.

\section{Konklusion}

På baggrund af undersøgelsens resultater kan det konkluderes, at såvel personer med demens som deres pårørende kan bidrage med væsentlig viden til idégenereringsfasen af produktudviklingen og herigennem give kritisk input til udviklingen af fremtidens GPS-løsninger. Det kræver dog en grundlæggende viden om demens og de udfordringer, som personerne oplever i deres hverdag, så man imødekommer deres kognitive udfordringer. Løsningerne bør understøtte deres 
ønske om bevægelsesfrihed, samtidig med at de skaber tryghed og sikkerhed hos såvel personer med demens som pårørende. GPS-løsningerne skal gerne støtte personerne med demens i selv at finde rundt i de tidlige stadier af sygdommen. Løsningerne skal samtidig kunne ændre sig i takt med sygdomsprogressionen, så de fortsat kan skabe tryghed, også hvis det er de pårørende, som betjener dem. Der eksisterer et etisk dilemma omkring overvågningsaspektet, da det kan opleves som en frihedsberøvelse af personerne med demens. På baggrund af undersøgelsens resultater ser det dog ud til, at tryghedsskabende demenssikringsteknologier er en mulighed og kan accepteres af såvel personer med demens som pårørende, hvis GPS-løsningen introduceres tidligt og frivilligt, og hvis det kun er nærmeste pårørende eller netværk, som har mulighed for at overvåge.

\section{Note}

1. Projektet er registeret $\mathrm{i}$ forhold til GDPR og fremlagt for Etisk Komite i Region Nordjylland. Projektet overholder Helsinki-deklarationens forskrifter (WMA 2013), hvor vi anså det for nødvendigt at involvere personer med demens i projektet for at opnå viden om, hvordan de oplever eksisterende GPS-løsninger, hvordan de finder vej, og hvilke ønsker de har til nye løsninger.

\section{Litteratur}

Aktiv med demens

2019 Aktiv med demens er et tilbud til mennesker med demens.

https://aktivmeddemens.dk/. Læst 14.5.2019.

Alz.org.

2015 Dementia.Signs, Symptoms, Causes, Tests, Treatment, Care | alz.org. http://www.alz.org/what-is-dementia.asp. Læst 13.5.2019.

Alzheimer Europe

2012 Informed Consent to Dementia Research. Ethics of Dementia Research - Ethical Issues in Practice - Ethics - Alzheimer Europe. http://www.alzheimer-europe.org/ Ethics/Ethical-issues-in-practice/Ethics-of-dementia-research/Informed-consentto-dementia-research\#fragment-1.Læst 13.5.2019.

Bjørner, Thomas

2015 Data Collection. In: T. Bjørner (ed.): Qualitative Methods for Consumer Research. The Value of the Qualitative Approach in Theory and Practice. Pp. 57-96.

København: Hans Reitzels Forlag.

Braun, Virginia \& Victoria Clarke

2006 Using Thematic Analysis in Psychology. Qualitative Research in Psychology 3(2):

77-101. DOI:10.1191/1478088706qp063oa.

Clarke, Victoria \& Virginia Braun

2013 Teaching Thematic Analysis. Methods 26(2)120-23. DOI:10.1191/

1478088706qp063oa. 
Cornwall, Andrea \& Rachel Jewkes

1995 What is Participatory Research? Social Science \& Medicine 41(12):1667-76. DOI: 2048/10.1016/0277-9536(95)00127-S.

Dewar, Belinda J.

2005 Beyond Tokenistic Involvement of Older People in Research. A Framework for Future Development and Understanding. Journal of Clinical Nursing 14(1):48-53. DOI:10.1111/j.1365-2702.2005.01162.x.

Dougall, Nadine J., Sjoerd Bruggink \& Klaus P. Ebmeier

2004 Systematic Review of the Diagnostic Accuracy of 99mTc-HMPAO-SPECT in Dementia. The American Journal of Geriatric Psychiatry 12(6):554-70. DOI: 10.1007/978-0-387-79948-3_642.

Evans, Joanna, Michael Brown, Tim Coughlan, Glyn Lawson \& Michael P. Craven

2015 A Systematic Review of Dementia Focused Assistive Technology. In: M. Kurosu (ed.): Human-Computer Interaction. Interaction Technologies. 17th International Conference, HCI International 2015, 2.-7. august. Los Angeles, CA, USA. Proceedings, Part II. Pp. 406-17. Basel: Springer.

Groes, Line

2015 Six Specific Methods for User Insight. In: T. Bjørner (ed.): Qualitative Methods for Consumer Research. The Value of the Qualitative Approach in Theory and Practice. Side 177-87. København: Hans Reitzels Forlag.

Hammersley, Martyn \& Paul Atkinson

2007 Ethnography. Principles in Practice. London: Routledge.

Hanson, Elizabeth, Lennart Magnusson, Helene Arvidsson, Anette Claesson, John Keady \& Mike Nolan

2007 Working Together with Persons with Early Stage Dementia and Their Family Members to Design a User-Friendly Technology-Based Support Service. Dementia 6(3):411-34. DOI:10.1177/1471301207081572.

Heggestad, Anne K.T., Per Nortvedt \& Åshild Slettebø

2012 The Importance of Moral Sensitivity when Including Persons with Dementia in Qualitative Research. Nursing Ethics 20(1):30-40. DOI:10.1177/ 0969733012455564.

Hellström, Ingrid, Mike Nolan \& Ulla Lundh

2007 Ethical and Methodological Issues in Interviewing Persons with Dementia.

Nursing Ethics 14(5):608-19. DOI:10.1177/0969733007080206.

Holthe, Torhild, Liv Halvorsrud, Dag Karterud, Kari-Anne Hoel \& Anne Lund

2018 Usability and Acceptability of Technology for Community-Dwelling Older Adults with Mild Cognitive Impairment and Dementia. A Systematic Literature Review.

Clin Interv Aging 13:863-86. DOI:10.2147/CIA.S154717.

Hubbard, Gill

2003 Including Older People with Dementia in Research. Challenges and Strategies. Aging and Mental Health 7(5):351-62. DOI:10.1080/1360786031000150685.

Kitwood, Tom

1997 Dementia Reconsidered. The Person Comes First. Buckingham: Open University Press. 
Landau, Ruth, Shirli Werner, Gail K. Auslander, Noam Shoval \& Jeremia Heinik

2009 Attitudes of Family and Professional Care-Givers towards the Use of GPS for Tracking Patients with Dementia. An Exploratory Study. The British Journal of Social Work 39(4):670-92. DOI:10.1093/bjsw/bcp037.

Lindsay, Stephen, Daniel Jackson, Cassim Ladha, Karim Ladha, Katie Brittain \& Patrick Olivier 2012 Empathy, Participatory Design and People with Dementia. CHI '12 Proceedings of the SIGCHI Conference on Human Factors in Computing Systems. Pp. 521-30. DOI: $10.1145 / 2207676.2207749$.

Mahoney, Edward L. \& Diane F. Mahoney

2010 Acceptance of Wearable Technology by Pople with Alzheimer's Disease. Issues and Accommodations. American Journal of Alzheimer's Disease and Other Dementias 25(6):527-31. DOI:10.1177/1533317510376944.

McKeown, Jane

2010 Actively Involving People with Dementia in Qualitative Research. Journal of Clinical Nursing 19(13-14):1935-43. DOI:10.1111/j.1365-2702.2009.03136.x.

Meiland, Franka, Anthea Innes, Gail Mountain Gail, Louise Robinson, Henriette van der Roest, Antonio J. García-Casal, Dianne Gove, Jochen R. Thyrian, Shirley Evans, RoseMarie Droes, Fiona Kelly, Alexander Kurz, Dympna Casey, Dorota Szczesniak, Tom Dening, Michael P. Craven, Marijke Span, Heike Felzmann, Magda Tsolaki \& Manuel Franco-Martin

2017 Technologies to Support Community-Dwelling Persons with Dementia. A Position Paper on Issues Regarding Development, Usability, Effectiveness and CostEffectiveness, Deployment, and Ethics. JMIR Rehabil Assist Technol 4(1):1-21. DOI:10.2196/rehab.6376.

Miyamoto, Yuki, Hiroto Ito, Toshio Otsuka \& Hiroshi Kurita

2002 Caregiver Burden in Mobile and Non-Mobile Demented Patients. A Comparative Study. International Journal of Geriatric Psychiatry 17(8):765-73. DOI:10.1002/ gps.694.

Møller, Anders K. \& Trine S. Christensen

2018 Designing Electronic Tracking and Tagging Solutions for People with Dementia. Experiences from a Public-Private Project Collaboration. Dementia Lab 2018 Proceedings. DOI:10.6084/m9.figshare.9936422.v1.

Nationalt Videnscenter for Demens

2014 Ny prognose for antal demensramte i Danmark. http://www.videnscenterfordemen s.dk/nyheder/2014/03/ny-prognose-for-antal-demensramte-i-danmark/.

OTIOM

2019 OTIOM Fordi ingen skal frygte at blive væk. https://otiom.com/.

Rafii, Michael S. \& Paul S. Aisen

2009 Recent Developments in Alzheimer's Disease Therapeutics. BMC Medicine 7(7). DOI:10.1186/1741-7015-7-7.

Robinson, Louise, Katie Brittain, Stephen Lindsay, Daniel Jackson \& Patrick Olivier $2009 \quad$ Keeping in Touch Everyday (KITE) Project. Developing Assistive Technologies with People with Dementia and their Carers to Promote Independence. International Psychogeriatrics 21(3):494-502. DOI:10.1017/S1041610209008448. 
Sanders, Elizabeth B.-N.

2002 From User-Centered to Participatory Design Approaches. In: J. Frascara (ed.): Design and the Social Sciences. Making Connections. Pp. 1-8. London \& New York: Taylor \& Francis.

Span, Marijke, Marike Hettinga, Myrra Vernooij-Dassen, Jan Eefsting \& Carolien Smits 2013 Involving People with Dementia in the Development of Supportive IT Applications. A Systematic Review. Ageing Res Rev 12(2):535-51. DOI:10.1016/ j.arr.2013.01.002.

Stacciarini, Jeanne-Marie, Mona Shattell, Maria Coady \& Brenda Wiens

2011 Review. Community-Based Participatory Research Approach to Address Mental Health in Minority Populations. Community Mental Health Journal 47(5):489-97. DOI:10.1007/s10597-010-9319-z.

Suijkerbuijk, Sandra, Henk Nap, Lotte Cornelisse, Wijnand IJsselsteijn, Yvonne de Kort \& Mirella Minkman

2019 Active Involvement of People with Dementia. A Systematic Review of Studies Developing Supportive Technologies. Journal of Alzheimer's Disease 69:1041-65. DOI:10.3233/JAD-190050.

Sundheds- og Ældreministeriet

2016 Statusrapport på demensområdet i Danmark. https://www.sum.dk/ /media/ Filer\%20-\%20Publikationer_i_pdf/2016/Statusrapport-demens-2016/ Statusrapport-paa-demensomraadet-i-dk.pdf. Læst 13.5.2019. Et trygt og værdigt liv med demens. national demens-handlingsplan 2025. http: //www.sum.dk/Aktuelt/Publikationer/ /media/Filer\%20-20Publikationer_i_pdf/ 2017/Demenshandlingsplan-2025-Et-trygt-og-vaerdigt-liv-med-demens/ Demenshandlingsplan-2025-Et-trygt-og-vaerdigt-liv-med-demens.ashx. Læst 14.5.2019.

Sundhedsstyrelsen

2019 Forskning til gavn for mennesker med demens og deres pårørende - national forskningsstrategi for demens 2025. https.//www.sst.dk/da/udgivelser/2018/ / media/1287247E536D437783E80FD514B9156B.ashx. Læst 14.5.2019.

Tanner, Denise

2012 Co-Research with Older People with Dementia. Experience and Reflections. Journal of Mental Health 21(3):296-306. DOI:10.3109/09638237.2011.651658.

Thoft, Diana S.

2017 Involving People with Earlystage Dementia in Qqualitative Research about Their Lifeworld Perspectives. Aalborg: Aalborg University Press.

Thoft, Diana S., Michelle Pyer, Anders Horsbøl \& Jacqueline Parkes

2018 The Balanced Participation Model. Sharing Opportunities for Giving People with Early-Stage Dementia a Voice in Research. Dementia 0(0):1-20. DOI:10.1177/ 1471301218820208 .

Videncenter for demens Aalborg Kommune

2019 Skoletilbud til borgere med demens i tidligt stadie. https://demens.aalborg.dk/ yngre-med-demens/skoletilbud-til-personer-med-demens-i-tidligt-stadie. Læst 14.5.2019.

Wan, Lin, Claudia Müller, Volker Wulf \& David W. Randall

2014 Addressing the Subtleties in Dementia Care. Pre-Study \& Evaluation of a GPS Monitoring System. Paper presented at the CHI 2014, One of a CHInd, Toronto, ON, Canada. Pp. 3987-96. DOI:10.1145/2556288.2557307. 
White, Eleanor B. \& Paul Montgomery

2014 Electronic Tracking for People with Dementia. An Exploratory Study of the Ethical Issues Experienced by Carers in Making Decisions about Usage.

Dementia 13(2):216-32. DOI:10.1177/1471301212460445.

Wilkinson, Heather

2002 Including People with Dementia in Research. Methods and Motivation. In: H. Wilkinson (ed.): The Perspectives of People with Dementia. Research Methods and Motivations. Pp. 9-24. London: Jessica Kingsley Publishers.

Winblad, Bengt, Philippe Amouyel, Sandrine Andrieu, Clive Ballard, Carol Brayne et al.

2016 Defeating Alzheimer's Disease and Other Dementias. A Priority for European Science and Society. The Lancet Neurology 15(5):455-532. DOI:10.1016/S14744422(16)00062-4.

WMA

2013

WMA declaration of Helsinki. Ethical Principles for Medical Research Involving Human Subjects. http://www.wma.net/en/30publications/10policies/b3/. Læst 10.5.2019.

Yu, Fang

2009

Cognitive Training for Early-Stage Alzheimer's Disease and Dementia. Journal of Gerontological Nursing 35(3):23-29. DOI:10.3928/00989134-20090301-10. 